NBER WORKING PAPER SERIES

\title{
A UNIFYING MODEL OF HOW THE TAX SYSTEM AND GENERALLY ACCEPTED ACCOUNTING PRINCIPLES AFFECT CORPORATE BEHAVIOR
}

\author{
Douglas A. Shackelford \\ Joel Slemrod \\ James M. Sallee \\ Working Paper 12873 \\ http://www.nber.org/papers/w12873
NATIONAL BUREAU OF ECONOMIC RESEARCH
1050 Massachusetts Avenue
Cambridge, MA 02138
January 2007

We are grateful for comments from Alan Auerbach, Dhammika Dharmapala, Jana Smith Raedy, Leslie Robinson, Terry Shevlin, Ryan Wilson and participants at the Conference on the Intersection of Financial Accounting and Tax Policy, held in Washington, D.C. on December 6, 2006 and at the NBER in Cambridge, MA on December 7, 2006 and the NBER pre-conference meeting held in Cambridge MA on July 27, 2006; we thank Joanne Hsu for research assistance. The views expressed herein are those of the author(s) and do not necessarily reflect the views of the National Bureau of Economic Research.

(C) 2007 by Douglas A. Shackelford, Joel Slemrod, and James M. Sallee. All rights reserved. Short sections of text, not to exceed two paragraphs, may be quoted without explicit permission provided that full credit, including $(C$ notice, is given to the source. 
A Unifying Model of How the Tax System and Generally Accepted Accounting Principles Affect Corporate Behavior

Douglas A. Shackelford, Joel Slemrod, and James M. Sallee

NBER Working Paper No. 12873

January 2007

JEL No. H21,H25,M41

\section{$\underline{\text { ABSTRACT }}$}

This paper models the impact of the tax system and GAAP on the real and financial reporting decisions of corporations. It provides a first step toward joint evaluation of taxation and financial reporting in the standard economic analyses of corporate behavior. The key finding is that value arises from real decisions that provide firms with discretion in their tax and financial reporting. This desire for flexibility modifies the optimal decisions of firms, in theory, and we provide examples that illustrate this behavior in the real world.

Douglas A. Shackelford

Kenan-Flagler Business School

University of North Carolina, Chapel Hill

Campus Box 3490, McColl Building

Chapel Hill, NC 27599-3490

and NBER

doug_shack@unc.edu

Joel Slemrod

University of Michigan Business School

Wyly Hall, Room 7719

Ann Arbor, MI 48109-1234

and NBER

jslemrod@umich.edu
James M. Sallee

University of Michigan Business School

Ann Arbor, MI 48109-1234

jsallee@umich.edu 


\section{A Unifying Model of How the Tax System and Generally Accepted Accounting Principles Affect Corporate Behavior}

\section{Introduction}

This paper models the effect of the tax system and financial reporting principles on the real and accounting decisions of corporations. Its purpose is to enhance our understanding of the effects of taxation and accounting on corporate behavior by merging the approach taken by economists and accountants. Economists typically study the effects of taxes on real decisions, ignoring the role of financial reporting. ${ }^{1}$ Accountants usually focus on the coordination of tax and accounting choices, with little attention to real economic effects (see review in Shackelford and Shevlin, 2001). ${ }^{2}$ Both approaches yield important insights, but neither is complete because tax and accounting decisions interact in important ways that affect real decisions. For example, a given tax policy may induce a real response that, in turn, facilitates advantageous financial disclosures. As a result, studies of real choices that ignore the incentives, constraints, and interaction of taxes and financial reporting may lead to spurious conclusions. Therefore, a unifying framework that incorporates both tax and accounting choices is needed to interpret corporate behavior.

This paper provides a first step toward joint evaluation of taxation and financial reporting in the standard economic analyses of corporate behavior. It develops a framework that formalizes the idea that the attractiveness of some real decisions is enhanced because they provide managers with discretion over the timing of taxable income and/or book income. The key finding is that, to the extent managers value flexibility in their tax and financial reporting, they are more likely to make real decisions that provide discretion. This desire for flexibility modifies the optimal decisions of firms, in theory, and we provide examples that illustrate this behavior in the real world.

\footnotetext{
${ }^{1}$ An extensive empirical literature in economics explores the effects of taxes on numerous real decisions. For a sample of the work, see reviews of investment decisions in Hassett and Hubbard (2002) and Hassett and Newmark (2006) and corporate finance in Graham (2003).

${ }^{2}$ Slemrod's (1992) trichotomy of behavioral responses to taxation illustrates the division between the tax work of economists and accountants: (1) real responses-the traditional domain of economists; (2) responses that reshuffle, relabel, or recharacterize the real activities of the taxpayer-the traditional domain of accountants; and (3) timing responses that take advantage of changing tax rules or rates-which both groups have studied to a limited extent.
} 
The paper proceeds in the following manner: Section 2 covers five topics around which we build the model. First, we discuss the fundamental role that information plays in both taxation and financial accounting. Both tax returns and financial statements convey inside information to outside stakeholders about the profitability of the firm, and these information asymmetries between the insiders and the external users are central to our modeling approach. Second, we develop the link between information and the corporate income tax. We note the administrative efficiencies of collecting large sums of tax from organizations with advanced information systems. However, they must be balanced against the opportunities for tax avoidance that this information provides. Third, we review the tax research in accounting that investigates whether firms will pay taxes to achieve accounting goals. Fourth, we discuss the tax and financial reporting costs associated with differences in accounting earnings and taxable income. Finally, we review the role that book-tax conformity plays in tax and accounting decisions.

Section 3 develops our model. Our objective is to provide a framework, as well as a vocabulary, that illustrates how accounting conventions and the tax law affect real business decisions. Among other results, we find that value arises from real decisions that provide firms with discretion in their tax and financial reporting.

Examples of this value follow in Section 4. Specifically, we examine how the value of discretion can provide incentives for firms to undertake more risky investments, to move their operations abroad, and to invest in activities with high legal and factual ambiguity. We discuss some policy implications in Section 5, and offer some concluding remarks in Section 6. 


\section{Building Blocks for the Model}

\subsection{Information}

Information (particularly information asymmetry) is at the core of the modern normative economics approach to taxation, known as optimal tax theory. According to optimal tax theory, if the tax authority could costlessly observe everything about taxpayers, taxes could be collected with no excess burden because individual tax liability could be based on an inalterable correlate of individual well being, call it ability. Because ability cannot be measured well, governments must base tax liability on alterable second-best correlates of well-being such as income, consumption, or wealth. Because they are alterable, taxing them causes behavioral responses and therefore inefficiency. Thus, measurement and information are at the core of the normative economics theory of taxation.

Information is also at the core of financial accounting. The purpose of financial accounting is to provide information about business organizations. This information is central to the management of public corporations because hired, professional managers (rather than shareholders) exercise day-to-day control. These managers know more about the business than most shareholders do. Financial reports are a means by which managers convey their inside knowledge to external investors, reducing the information asymmetries and thus lowering the cost of obtaining capital. Financial accounting aids in the design of formal and informal contracting arrangements that induce managers to pursue shareholder-value-maximizing behavior, facilitates shareholder monitoring of business operations, and supplies a wide array of contractible variables that can be used to construct management compensation plans designed to align the interests of shareholders and managers.

Publicly-held U.S. companies have to provide financial information to two different audiences, each of whom has a stake in assessing how much income is being generated. One is a public accounting, to the firm's stakeholders: investors, creditors, customers, suppliers, employees, regulators, and rating services, among others. The other is a nonpublic accounting, to the Internal Revenue Service (IRS).

The IRS can see the public financial statements, which helps the IRS to better detect any understatement of taxable income. The value of seeing the public financial 
statements has been enhanced by the new Schedule M-3 of the tax return, which requires the company to provide detailed information that reconciles the information on the financial statements to the information on the tax return. Although investors cannot see the tax return and firms are not required to disclose any information from the tax return, including taxable income or the actual tax they pay, investors receive some information about taxes in the financial statements.

Firms report a different measure of income to each audience. The income reported in financial reports may differ from taxable income for at least three reasons. First, there are explicit differences in the intent of the two reports. Financial statements are designed to reduce asymmetric information problems through reliable and relevant disclosures. The tax return reflects policy that balances (often competing) economic objectives of equity, efficiency, and simplicity as well as political objectives to reward favored constituencies. Given the differences in the purposes of the financial statements and the tax return, it is not surprising that the most useful measure of a firm's profitability for shareholders usually differs from the most useful measure of profitability for the taxing authorities.

A second reason why book income and taxable income may differ is that while financial accounting strives to record the underlying economics of a transaction in an objective and verifiable way, much of the tax system is designed to induce or reward particular behavior. For example, for book purposes, the value of the firm's equipment is depreciated (an expense that reduces book income) each period based on estimates of the equipment's deterioration. For tax purposes, the value of the firm's equipment is depreciated (a deduction that reduces taxable income) each period by a statutorily determined amount, which may be intentionally altered by legislation to encourage acquisition of plant and equipment. Because the statutory depreciation for tax purposes generally differs from the estimate for financial reporting of the equipment's actual deterioration, book income and taxable income will differ.

A third reason why book income and taxable income may differ is that there are incentives to mislead both the audience for the financial statements and the audience for the tax return (i.e., the IRS) about ongoing operations. Both the tax return and the financial statement are snapshots of what the corporation wants some audience-either 
the IRS or the investing public - to see. For example, in a given year, firms may have particularly large incentives to look more profitable to their investors. Returning to the depreciation example, because determining deterioration is an imprecise process, managers have some leeway in the amount of book depreciation that they record. Thus, book depreciation becomes a means of managing book earnings, further creating differences in the two measures of income.

Both the IRS and the Security and Exchange Commission (SEC), which regulates public financial disclosures, have safeguards to protect against misleading reports. To ensure that it is receiving its appropriate share, the IRS receives millions of confidential—albeit potentially misleading — reports from businesses about their earnings. Audit decisions are based on comparisons of tax returns across time for the same taxpayer, across similar taxpayers in the same year, and with the information in the firm's financial statements.

On the book side, the SEC receives financial statements from all publicly-traded corporations. The financial disclosures must conform to Generally Accepted Accounting Principles (GAAP). Penalties for failure to comply include restating prior statements, losing access to the public capital markets, and criminal proceedings against managers.

GAAP comprises accounting conventions that have evolved over decades to provide guidance about the information that firms should disclose through their financial reports. GAAP provides a structure for identifying, evaluating, and reporting the firm's activities so that financial disclosures are relevant, reliable, comparable, and consistent. The Financial Accounting Standards Board (FASB), with oversight from the SEC, is the primary standard setter of GAAP. The American Institute of Certified Public Accountants, the Emerging Issues Task Force, and the SEC itself also contribute to GAAP. Each body promulgates statements to guide accountants who produce financial reports. Some standards mandate specific accounting treatment for a transaction. Other pronouncements suggest an approach or a structure for reporting transactions.

To summarize, any model of the impact of taxes on real and accounting decisions must begin by considering the role of information for both taxation and financial accounting. Firms report information about their operations to both the taxing authorities and the capital markets. The information in the two reports differs because the users 
differ and the firms' incentives differ. Although firms have some leeway in the information that they provide in tax returns and financial statements, both the IRS and the SEC limit their discretion by monitoring reports and ensuring that they are in line with the rules.

\subsection{Corporate Income Taxation}

In addition to its centrality for both tax and accounting, information is a principal justification for the corporate income tax. Rather than collect revenue from millions of shareholders and employees, the corporate income tax takes advantage of advanced accounting systems, already in place for non-tax reasons, to collect revenue from a relatively small number of corporations. Thus, in modern economies, large corporations serve important roles in the remittance of funds to the tax authority and the transmittal of tax-related information from the private to the public sector. As Bird (2002) has put it so eloquently, "The key to effective taxation is information, and the key to information in the modern economy is the corporation. The corporation is thus the modern fiscal state's equivalent of the customs barrier at the border." That said, the same advanced accounting systems, which produce the information that makes the corporation an efficient tax collector, facilitate sophisticated tax avoidance, challenging the notion that the corporation is still an efficient node of collection of tax triggered by income.

Information asymmetry also affects the firm's tax aggressiveness. Consider this question: Would managers be as tax-aggressive if the tax savings from aggressiveness accrued directly to the shareholders by lowering their personal tax liability? If the answer to this question is that they would be equally tax-aggressive, then the point of collection is immaterial. However, if the answer is no, then tax savings that accrue directly to the shareholders would not, on average, be pursued quite as aggressively by public corporations, and devolving remittance responsibility to shareholders might inhibit aggressiveness. A similar issue pertains to the management of book earnings-do the benefits accrue to managers, or shareholders, or both? Is earnings management 
opportunistic behavior by managers or does it improve the quality of communication, e.g., distinguishing permanent and transitory earnings? ${ }^{3}$

\subsection{Book-Tax Trade-offs}

We now shift from the role of information in tax and accounting to the largest body of tax research in accounting, studies of the effects of non-tax considerations on tax decisions. ${ }^{4}$ This literature builds on Scholes and Wolfson's (1992) insight that tax strategies affect other organizational goals and cannot be evaluated in isolation. Their work implies, inter alia, that tax minimization is generally not an optimal business strategy.

The non-tax consideration of primary interest to accountants is the financial reporting costs. Shackelford and Shevlin (2001, p.326) define financial reporting costs as “those costs, real or perceived, related to reporting lower income or shareholders' equity." $"$ These financial reporting costs often conflict with tax minimization because reductions in taxable income frequently result in lower book profits and/or equity. ${ }^{6}$ This tension forces firms to trade-off book and tax considerations. A primary finding in this literature is that firms will pay taxes (or forgo tax savings) to reduce financial reporting costs. ${ }^{7}$

There are at least two reasons why accounting information may be important to managers. ${ }^{8}$ First, many contracts, e.g., executive compensation, rely on the firm's accounting information to specify the terms of trade. If these contracts do not or cannot undo the potentially adverse book effects of tax-optimal strategies, then the accounting

\footnotetext{
${ }^{3}$ For further discussion, see Dechow and Skinner (2000, footnote 9), Abarbanell (2002), and Abarbanell and Lehavy (2003, footnote 3).

${ }^{4}$ See Shackelford and Shevlin (2001) for a review of this literature.

${ }^{5}$ A substantial portion of accounting research, outside the tax field, focuses on financial reporting costs. For reviews, see Kothari (2001) and Healy and Palepu (2001).

${ }^{6}$ For expositional purposes, in the remainder of the paper we will refer to the income statement effects of the financial reporting costs. However, any references to financial reporting costs should be interpreted as including all financial reporting costs associated with other disclosures in the financial statements.

${ }^{7}$ The research documenting that firms will pay taxes to reduce financial reporting costs is a subset of a larger body of knowledge showing that firms will pay cash (both through taxes and other means) to reduce financial reporting costs. For example, Lys and Vincent (1995), estimate that AT\&T paid an additional $\$ 500$ million in its 1991 acquisition of NCR solely to ensure adoption of an accounting treatment (pooling of interests) that would boost book income in future years, but would never affect cash flows.

${ }^{8}$ See Graham, Harvey and Rajgopal (2005) for extensive evidence that managers care about accounting earnings. Among other findings, they report that 78 percent of corporate executives report sacrificing longterm firm value to "smooth" (i.e., reduce the variability in) earnings.
} 
disclosures may affect behavior. Second, if the users of financial statements cannot distinguish between low earnings arising from poor profitability and low earnings arising from tax plans that increase cash flow at the expense of accounting earnings, then managers may be unwilling to minimize real taxes paid. More precisely, if managers believe that the users cannot distinguish, then they may forgo the perceived-unobservable tax benefits to enhance the observable book earnings.

Most book-tax trade-off studies identify settings where book income and taxable income are accounted for the same, e.g., if book income increases, then taxable income increases. The studies typically measure the extent to which firm forgo tax minimization because of financial reporting considerations, i.e., pay taxes to produce more favorable financial statements. They attempt to quantify the forgone tax savings of given decision that increase book income, sometimes estimating an "exchange rate" between book income and taxable income.

Two decades of the trade-off studies have produced substantial evidence across industries, transactions, countries and time that firms are willing to remit taxes (or forgo tax savings) to reduce financial reporting costs. Although space constraints prevent us from providing a thorough review of these book-tax studies, we briefly mention three studies to provide a flavor of this work:

- Examining a set of firms that fraudulently overstated their earnings, Erickson, Hanlon, and Maydew (2004) report that, on average, these firms paid 11 cents in additional federal taxes for every additional dollar of fraudulent accounting earnings.

- Matsunaga, Shevlin and Shores (1992) show that corporations could have lowered their tax liability by disqualifying their incentive stock options (i.e., converting them to non-qualified options) following the Tax Reform Act of 1986. However, the disqualification would have lowered book earnings. They estimate that the mean firm passed up tax benefits of $\$ 0.6$ million to avoid a 2.3 percent reduction in reported earnings. The few firms that did disqualify their incentive stock options were those with the strongest earnings, which may indicate that they were expecting a relatively small penalty for reporting lower earnings.

- Engel, Erickson, and Maydew (1999) analyze trust preferred stock, which is treated as equity for book purposes and debt for tax purposes. They report that, of the 44 companies that used trust preferred stock to retire debt, 15 companies could have retired traditional preferred stock. By choosing to retire debt (whose interest 
is deductible) rather than preferred stock (whose dividends are not deductible), these firms, on average, forwent tax benefits of $\$ 43$ million to avoid increasing their debt-to-assets ratio by 12.8 percent.

\subsection{Book-Tax Divergence}

Not all accounting and tax choices force trade-offs. For some transactions, book income and taxable income do not move together. When this happens, accounting profits and taxable income diverge. As noted above, book depreciation is based on an assessment of the deterioration of property, while tax depreciation is a statutorily determined amount that need not be related to the actual decline in the value of the property. Thus, differences in GAAP and the tax law cause part of the book-tax divergence in depreciation.

Some of the divergence between book and tax depreciation is at the discretion of the manager, because managers can choose among assorted methods of book depreciation. Keating and Zimmerman (2000) provide evidence consistent with managers considering the divergence in book and tax when they make their book depreciation choice. They find that the book life of depreciable assets moves with the statutory lives for tax depreciation purposes, although there is no GAAP or legal requirement for them to do so.

That managers would consider book-tax divergence when they make decisions is consistent with recent studies that document that book-tax divergence can be costlyboth increasing tax payments and financial reporting costs. ${ }^{9}$ Mills (1998) provides an example of increased tax costs arising from book-tax divergence. She uses confidential IRS data to demonstrate that firms with larger differences in book earnings and taxable income are more likely to be audited.

Hanlon (2005) provides an example of increased financial reporting costs arising from book-tax divergence. Using financial statement disclosures, she finds that the more book income and taxable income diverge, the more investors trade as though they consider the book earnings to be of lower "quality" (i.e., unlikely to persist).

\footnotetext{
${ }^{9}$ For a sampling of recent studies of book-tax differences, see Plesko (1999), Mills and Newberry (2001), Gleason and Mills (2002), Phillips, Pincus and Rego (2002), Desai (2003), Schrand and Wong 2003; Frank and Rego (2003), Lev and Nissim (2004), Hanlon, Maydew and Shevlin (2006) and Schmidt (2006), among many others.
} 
To summarize, differences in book income and taxable income can arise both from mandated differences in GAAP and the tax law and from discretionary financial accounting and tax choices. These divergences between book and tax are not neutral. They increase both tax and financial reporting costs and may serve as prima facie evidence that either the tax liability is understated or the reported book earnings are overstated.

\subsection{Conformity}

In recent years, the divergence between book income and taxable income has led to calls from some policy makers and scholars to force firms to report (more) transactions identically for book and tax purposes. ${ }^{10}$ From its inception, the corporate tax law has been built on the financial accounting system. In the absence of specific exceptions in the tax law, transactions continue to be treated the same for book and tax. However, over time, Congress has passed many provisions that specify a different treatment for tax than for GAAP. These tax-only provisions increase divergence between book accounting and tax accounting. ${ }^{11}$

Proponents of increased book-tax conformity (legislated, rather than the default form of conformity that now exists) argue that permitting or requiring firms to account for transactions one way for their shareholders and another way for the IRS produces misleading reports for both audiences, e.g., overstated accounting earnings and understated taxable income. Those who oppose conformity argue that the audiences should receive different information because the purposes and uses of financial reports and tax returns differ.

\footnotetext{
${ }^{10}$ See Hanlon and Shevlin (2005) and Hanlon and Maydew (2006) for a detailed analysis of the benefits and costs associated with book-tax conformity.

${ }^{11}$ One notable exception is LIFO, a method of computing inventory costs where Congress requires booktax conformity, i.e., a firm using LIFO for tax purposes also must use it for book purposes. As background, both tax law and GAAP permits firms to compute the costs of their inventory without regard to the actual flows of inputs. During inflationary periods, if recently acquired, high-cost inputs are assumed to be the ones that complete the production process first ("last-in, first-out", or LIFO), then the cost of inventory that is deducted on the tax return will be higher than if lower cost inputs are assumed to have completed the production process first. Because of the LIFO conformity rule, net income will also be lower. Thus, firms that wish to use LIFO for tax purposes must trade-off the tax advantages with any financial reporting costs associated with lower profits.
} 
While this paper takes no position on legislated book-tax conformity, it is relevant here because it would increase the number of situations in which firms would have to trade off book and tax incentives. The trade-off literature suggests that, in some situations, firms would take positions to enhance their book earnings (and thus arguably provide misleading tax reports) and at other times, they would take positions to reduce their tax liabilities (and thus arguably produce misleading financial reports). ${ }^{12}$ Either way, more book-tax conformity would increase the need for managers to coordinate their book and tax choices while reducing the current financial accounting and tax costs associated with book-tax divergence.

\section{Model}

\subsection{The Basic Setup}

The theoretical and empirical research cited above highlights several things that a comprehensive model must address. First, a model should allow for the possibility that firms value book income as well as after-tax real income. It should also allow for the possibility that, at the margin, firms care about book income in one period more than in another. Second, book income and taxable income are not necessarily equal. They may differ because accounting conventions require one treatment of an action but the tax system requires something different. Differences may also arise because tax or accounting rules give a firm discretion, so that differences are the result of strategic choices. Third, when book income and taxable income diverge, it may be costly to the firm. Finally, a comprehensive model should be able to address the consequences of required conformity between the tax system and accounting standards. In this section, we incrementally develop a model that has these features.

Although in the previous section we emphasized the role of information, we will not formally model asymmetric information. We do not formally model the role of information because it is difficult and necessitates a narrow focus on one or a small set of agency problems. Instead, we employ a reduced-form model that allows for the uncontroversial possibility that in equilibrium the decision makers (henceforth managers) employed at public companies care about book earnings, conditional on the underlying

\footnotetext{
${ }^{12}$ See Shackelford and Shevlin (2001) for examples.
} 
"real" profitability (cash flows) of the corporation's operations. This is a natural result of there being some information that is private to managers that makes it (privately, not necessarily socially) optimal for the manager's compensation to be based on earnings reports. ${ }^{13}$ When executive compensation is set so that the incentives of the manager and the shareholders are optimally aligned, then the manager's maximizing this function will also be in the shareholders' interest. In this case, the ability to move book income may allow a manager to signal private information, as discussed in Sankar and Subramanyam (2001). Even in the absence of asymmetric information between owners and managers, the ability to shift book income may be valuable because contracts and debt covenants may (optimally) be written in terms of financial variables. Note, though, as Crocker and Slemrod (forthcoming) show, although an optimal compensation scheme should be designed with an eye on deterring misleading reporting by the firm's officers, it should not eliminate earnings manipulation, because doing so would excessively constrain the ability of the shareholders to incentivize the manager to take the appropriate actions that maximize profits. In the model we develop below, managers have some ability to shift book income across periods, but cannot appropriate funds from the corporation.

One implication of this is that the tradeoff between cash flows and book income will vary across types of corporations and within corporations across periods. For example, Barth, Beaver and Landsman (1998) find that as a firm's financial health decreases, its accounting earnings becomes less important in the valuation of the firm while its book value (which better measures the firm's cash liquidation value) becomes more important. Conversely, accounting earnings are more useful than cash measures in assessing the rents associated with future growth opportunities and other unrecognized assets.

The reduced-form approach hampers normative analysis of tax and accounting policy because it does not explicitly account for the extent to which managerial incentives are aligned with shareholders' incentives nor does it address the social benefits of access to information and how they might change when policy changes; it is a positive analysis of the impact of tax policy on corporate behavior. The reduced-form approach is also likely to be misleading about the impact on corporate decisions of certain non-

\footnotetext{
${ }^{13}$ Of course compensation contracts may also be contingent on the company's share price.
} 
incremental policy changes. For example, if a the penalty for accounting fraud or tax noncompliance was shifted from the corporation to the manager, this would affect the structure of the optimal compensation contract, which in turn would affect the objective function of the decision maker; the analysis that follows applies to policy changes that leave the objective function unchanged. .

The model also assumes perfect certainty although, in reality, uncertainty abounds and firms make real and accounting decisions based on their beliefs about the future. In an uncertain world, a firm might expend resources to achieve discretion in its reporting that has expected value but ultimately provides no benefit to the firm. For example, a firm may suspect that its marginal tax rate next period will be lower than it is today, perhaps because it expects a net operating loss in the next period. As a result, it may choose one investment project over another because the former produces slack in the timing of tax income and the firm would like to shift taxable income forward. Next period earnings, however, may be unexpectedly strong, so that the marginal tax rate is unchanged. In such a case, slack was created, perhaps at a cost, but ex post, it produced no benefits for the firm. Although we could recast our two-period model of certainty to allow uncertainty about future cash flows and future tax policy, we believe that this would introduce more notational complexity than is justified by the additional insights. Nevertheless, we believe it is appropriate to think about our results as pertaining to a world of probabilistic decision-making.

With these qualifications, we assert that a company makes decisions in order to maximize an objective function that includes both the present value of after-tax cash flows and the financial accounting expression of those cash flows as after-tax book earnings (income) in each of two periods, referred to as period 1 and period 2. A twoperiod horizon is the minimal one that allows us to address shifting across time of taxable and book income.

We write this objective function as follows:

$$
\mathrm{M}\left(\tilde{C}^{1}+\delta \tilde{C}^{2}, \tilde{Y}_{B}^{1}, \delta \tilde{Y}_{B}^{2}\right),
$$

where $\tilde{C}^{i}$ refers to after-tax cash flows in period $i, \delta$ is the economic discount factor on cash flows, and $\tilde{Y}_{B}^{i}$ refers to after-tax book profits in period $i$. The relationship between cash flows and book income is worth noting: (a) total undiscounted cash flows equal total 
undiscounted book income over the two periods combined; (2) in any single period, book income equals cash flows plus accounting accruals.

We assume that the function $\mathrm{M}$ is concave, differentiable, and use $M_{i}$ to denote the partial derivative of $\mathrm{M}($.$) with respect to the i$ th argument of the function. We use tildes to denote after-tax outcomes to eliminate the need for an additional subscript. Superscripts denote the period, while subscripts denote variables that are defined and measured by the tax system ( $\mathrm{T}$, for tax) or GAAP (B, for book), respectively. Parentheses denote functions, not multiplication.

The standard economics modeling of real business decisions would include only the first argument of this function, ignoring the possibility that firms might value accounting earnings. Our setup allows the firm to trade off book income and cash flows. Indeed, $M_{2} / M_{1}$ represents the "exchange rate", or tradeoff, between the current period's financial reporting considerations (in this case, book income) and cash flow that so many accounting studies, briefly described in Section 2, have addressed. Assuming that the book income implications must eventually reverse, it is probably best to think of, for example, the tradeoff of 0.11 (i.e., 11 cents of tax for one dollar of earnings), estimated by Erickson, Hanlon, and Maydew (2004), as reflecting $\left(M_{2}-\delta M_{3}\right) / M_{1}{ }^{14}$

The framework also accommodates the possibility that firms value an additional dollar of (discounted) book income in one period more than in another. This may be the case, for example, if a manager seeks to smooth earnings, create an upward trend in earnings, maximize compensation that is determined on a period-specific basis, such as bonuses (see Healy, 1985) or meet some other earnings target. We include the discount factor, $\delta$, as a multiplicative factor on the second-period book income simply as a notational matter to provide symmetry with the discounting of cash flows. It implies that if $M_{2}$ (the marginal value of first-period book income) were to equal $M_{3}$ (the marginal value of second-period income), then the company would be indifferent at the margin between first-period book income and the discounted present value of second-period book income; however, the objective function is flexible enough so that, when $M_{2}$ does

\footnotetext{
${ }^{14}$ In Erickson, Hanlon, and Maydew (2004), 0.11 is the ratio of total cash flow costs to total book income increases, while $\left(M_{2}-\delta M_{3}\right) / M_{1}$ is a ratio of marginal values.
} 
not equal $M_{3}$, this need not be true. Indeed, when $M_{2}=\delta M_{3}$, the company is indifferent, at the margin, between undiscounted book earnings in the two periods.

Central to our model is how the tax code and GAAP transform cash flows into measures of taxable income and book earnings, respectively. To accommodate the fact that neither the tax system nor GAAP treats all types of cash flows equivalently, we explicitly distinguish a variety of cash flow categories $(j=1, \ldots, J)$ that may be treated differently by either the tax code or GAAP. Equation 2 expresses the total after-tax cash flow in a period as the sum of pre-tax cash flows over these $\mathrm{J}$ categories minus taxes paid $\left(T^{i}\right)$

$$
\tilde{C}^{i}=\sum_{j} C_{j}^{i}-T^{i} \quad \text { for } i=1,2
$$

Equation 3 defines taxes paid in a period as a function of taxable income in that period, such that $\mathrm{T}^{\mathrm{i}}($.$) is the tax code schedule that relates tax liability to taxable income.$ For simplicity, we assume that one period's taxable income cannot affect another period's tax liability. ${ }^{15}$

$$
T^{i}=\mathrm{T}^{\mathrm{i}}\left(Y_{T}^{i}\right) \quad \text { for } i=1,2
$$

Equation 4 defines taxable income, which depends on the categories of cash flows in both periods. We write this function in a very general way to allow for the possibility that two streams of cash, even if they are identical in every period, may have different implications for taxable income. The notation $\mathbf{C}^{\mathbf{i}}$ represents the vector of cash flow categories in period $\mathrm{i}$.

$$
Y_{T}^{i}=\mathrm{Y}_{\mathrm{T}}^{\mathrm{i}}\left(C_{1}^{1}, \ldots, C_{J}^{1} ; C_{1}^{2}, \ldots, C_{J}^{2}\right)=\mathrm{Y}_{\mathrm{T}}^{\mathrm{i}}\left(\mathbf{C}^{\mathbf{1}}, \mathbf{C}^{2}\right) \quad \text { for } i=1,2
$$

Equation 5 is straightforward: after-tax book income $\left(\tilde{Y}_{B}^{i}\right)$ is the pretax book income from a period $\left(Y_{B}^{i}\right)$ minus the book tax provision $\left(T_{B}^{i}\right)$.

$$
\tilde{Y}_{B}^{i}=Y_{B}^{i}-T_{B}^{i} \quad \text { for } i=1,2
$$

The "book tax provision" is the expense for income taxes that is recorded in financial statements. It is the past, present and estimated future taxes triggered by economic activity in the period. Thus, equation 6 defines a single period's book tax

\footnotetext{
${ }^{15}$ This assumption prevents us from directly addressing the implications of limited tax loss refundability, loss carryforward and carryback rules. This could be easily introduced, though at the cost of further notational complexity.
} 
provision as a function of taxes paid to the IRS in both periods. Over the life of the firm (two periods in this model), the sum of the book tax provisions equals the sum of taxes paid. Since the sum of pre-tax book income equals the sum of pre-tax cash flows, then the sum of after-tax book income equals the sum of after-tax cash flows. ${ }^{16}$

$$
T_{B}^{i}=\mathrm{T}_{\mathrm{B}}^{\mathrm{i}}\left(T^{1}, T^{2}\right) \quad \text { for } i=1,2
$$

Equation 7 defines book income. As with income for tax purposes, book income depends in a general way on the cash flows, depending on the category of cash flow. Critically, the function that maps cash flows into book income is distinct both from the $\mathrm{Y}_{\mathrm{T}}^{\mathrm{i}}($.) function that determines taxable income, and from the discounted cash flow.

$$
Y_{B}^{i}=\mathrm{Y}_{\mathrm{B}}^{\mathrm{i}}\left(C_{1}^{1}, \ldots, C_{J}^{1} ; C_{1}^{2}, \ldots, C_{J}^{1}\right)=\mathrm{Y}_{\mathrm{B}}^{\mathrm{i}}\left(\mathbf{C}^{1}, \mathbf{C}^{2}\right) \quad \text { for } i=1,2
$$

\subsection{Discretion and shifting}

We next introduce the concept of discretion. In our model, a firm has discretion to the extent that it is able to shift pre-tax book income, taxable income, or the book tax provision across time. ${ }^{17}$ The amounts shifted are introduced as choice variables, $S_{T}$ and $S_{B}$, which denote income shifting for tax and book purposes, respectively, and $P_{B}$, which denotes the shifting of the book tax provision.

These choice variables are subject to a constraint. For any given set of real decisions made by the firm there is a limited amount of discretion in book income, taxable income, and the book tax provision. Given the maximum available slack, the

\footnotetext{
${ }^{16}$ Here is a simple numerical example of accounting for income taxes. Suppose (a) income (for both book and tax purposes) is $\$ 10$ before considering depreciation; (b) book depreciation is $\$ 5$ in both the first and second period; (c) tax depreciation is $\$ 10$ in the first period and zero in the second period (i.e., immediate expensing); and (d) the tax rate is 40 percent. The book tax provision in both periods is $\$ 2$ [(10-5)(0.4)]. Book net income, after depreciation and taxes, is $\$ 3$ (10-5-2) in both periods. Zero (4) actual taxes are paid in the first (second) year. In the balance sheet at the end of the first year, the firm records a deferred (i.e., future) tax liability of $\$ 2$, representing the $\$ 2$ of tax to be paid in the second period. At the end of the second period, the liability of $\$ 2$ is removed from the balance sheet, recognizing the actual payment of those taxes. Thus, although the expensing for tax purposes has the effect of accelerating cash flows, it has no effect on the accounting earnings. The reason is that GAAP is designed to capture the taxes across all periods related to the economic activity in this period, regardless of when the actual taxes paid. One way to think about this recording of book taxes is that the equipment produced \$20 in revenue over two years. During thse two years, $\$ 4$ of taxes were paid. GAAP records those $\$ 4$ of taxes over the equipment's life, rather than in accordance with the actual timing of the tax payments to the government.

${ }^{17}$ Readers likely can readily identify examples of shifting pre-tax book or taxable income. An example of shifting the book tax provision is the decision to report foreign earnings as permanently reinvested, a choice we detail in Section 4.2.
} 
firm chooses a level of shifting to maximize its objective function, $M$. As defined, a positive $S_{T}$ defers taxable income, and therefore tax payments, to the second period and so moves after-tax cash flows up to the first period. Similarly, a positive value of $S_{B}$ moves book income to the second period. Every dollar of pre-tax book income shifted requires that $\tau$ dollars of book tax provision be booked in the second period, where $\tau$ is the statutory tax rate on corporate income. A positive value of $P_{B}$ denotes shifting of the book tax provision to the second period, and thus reduces after-tax book income in the second period. By definition, shifting allows the firm to move recognition across periods, but it does not change the undiscounted total of taxable income, book income, or the book tax provision.

The key to our model is that we will allow each type of discretion to be a function of the firm's real actions. If a firm undertakes a set of activities, these activities will generate some level of discretion. Given this discretion, the firm will choose the optimal amount of shifting. The interaction between "normal" business operations and shifting comes from the fact that firms recognize the value of discretion, and, therefore, ceteris paribus, prefer actions that create discretion. The model makes a sharp distinction between discretionary and non-discretionary choices. This distinction is meant to indicate that there is a class of choices that are well understood and signal nothing about either tax or book aggressiveness. In practice, however, the distinction between discretionary and non-discretionary choices is less clear to the users of financial statements, the IRS, and researchers. Although by assumption income shifting pertains to temporary, rather than permanent, differences between book and tax accounting, our formulation of the $Y_{B}$ and $Y_{T}$ functions is general enough to allow permanent differences between book and tax, so that the book "effective tax rate," defined as the ratio of the (total) book tax provision to book pre-tax earnings, need not equal the statutory tax rate.

We introduce one final wrinkle. As detailed above, in some circumstances both the capital markets and the IRS may believe that book-tax differences signal potential manipulation of financial information. Thus, it may be costly for firms when discretionary shifts of taxable $\left(S_{T}\right)$ and book income $\left(S_{B}\right)$ diverge. To capture this notion, we define the function $\Omega$ :

$$
\Omega=\Omega\left(S_{B}-S_{T}\right),
$$


where $\Omega(0)=0$. To incorporate any costs associated with book-tax differences, we subtract the cost from first-period book income and first-period cash flow (and assume it is subtracted in the calculation of taxable income).

When we add the notion of discretion, the capacity to shift, and the cost of divergence, the equations defining after-tax cash flows and book income become

$$
\begin{aligned}
& \tilde{C}^{1}=\sum_{j} C_{j}^{1}-\mathrm{T}^{1}\left(\mathrm{Y}_{\mathrm{T}}^{1}\left(\mathbf{C}^{1}, \mathbf{C}^{2}\right)-S_{T}-\Omega\left(S_{B}-S_{T}\right)\right)-\Omega\left(S_{B}-S_{T}\right) \\
& \tilde{C}^{2}=\sum_{j} C_{j}^{2}-\mathrm{T}^{2}\left(\mathrm{Y}_{\mathrm{T}}^{2}\left(\mathbf{C}^{1}, \mathbf{C}^{2}\right)+S_{T}\right) \\
& \tilde{Y}_{B}^{1}=\left[\mathrm{Y}_{\mathrm{B}}^{1}\left(\mathbf{C}^{1}, \mathbf{C}^{2}\right)-S_{B}-\Omega\left(S_{B}-S_{T}\right)\right]-\left[\mathrm{T}_{\mathrm{B}}^{1}\left(T^{1}, T^{2}\right)-\tau S_{B}-P_{B}\right] \\
& \tilde{Y}_{B}^{2}=\left[\mathrm{Y}_{\mathrm{B}}^{2}\left(\mathbf{C}^{1}, \mathbf{C}^{2}\right)+S_{B}\right]-\left[\mathrm{T}_{\mathrm{B}}^{2}\left(T^{1}, T^{2}\right)+\tau S_{B}+P_{B}\right]
\end{aligned}
$$

The fact that the firm is constrained in its ability to shift taxable income and book income is represented by the expressions $\overline{S_{T}}, \overline{S_{B}}$ and $\overline{P_{B}}$, which are the maximum amount of shifting that the firm is able to perform under the tax code and GAAP. ${ }^{18}$ The model accommodates the idea that discretion may or may not be valuable to a firm, depending on their situation. As we elaborate on below, if an action creates additional discretion, this is only valuable if that discretion is to be used. Mathematically, discretion has marginal value if and only if the shifting constraints are binding. ${ }^{19}$

These constraints are written as:

$$
\begin{aligned}
& \left|S_{T}\right| \leq \overline{S_{T}} \\
& \left|S_{B}\right| \leq \overline{S_{B}} \\
& \left|P_{B}\right| \leq \overline{P_{\mathbf{B}}}
\end{aligned}
$$

\footnotetext{
${ }^{18}$ Implicitly, shifting that exceeds this limit is subject to unacceptably high IRS penalties or SEC sanctions. Note that, as an alternative to introducing caps, we could have posited a "cost of shifting function" that allows the firm to shift any amount while incurring a convex cost. The cost function could also take $D$ as an argument, allowing real decisions to shift the cost schedule. This is a common approach in the analysis of tax avoidance and income shifting. See Slemrod (2001) for an example in economics and Stocken and Verrecchia (2004) for an example in accounting.

${ }^{19}$ In the first-order conditions discussed later, this will be synonymous with a non-zero Lagrange multiplier.
} 


\subsection{Book-tax conformity}

Our model can address any form of book-tax conformity. As discussed above, many transactions are treated the same for book and tax purposes. If GAAP and tax treatment were always the same, i.e., complete book-tax conformity, then taxable income would equal pre-tax book income, and in terms of our notation, $Y_{B}$ would equal $Y_{T}$ in both periods. However, not all transactions are treated differently for book and tax. Thus, current practice is characterized by "partial conformity." Our notation easily accommodates the notion of partial conformity by requiring some subset of the cash flow categories to have identical effects on taxable income and book income.

We introduce an additional element of conformity to our analysis of discretion by allowing that there may be a constraint requiring $\mathrm{S}_{\mathrm{T}}$ to equal $\mathrm{S}_{\mathrm{B}} \cdot{ }^{20}$ In equation (16), the term $\mathrm{A}$ is a zero-one dummy variable indicating whether or not tax and book transfers must conform. ${ }^{21}$ If the government requires conformity, then $\mathrm{A}=1$, and the transfer of book income must match the transfer of tax income. If the government does not require conformity, then $\mathrm{A}=0$, and the tax shifting may differ from the book shifting. Conformity generates interaction by linking the values of book and tax discretion. For example, additional discretion in book income might be valuable even if a firm is indifferent to the timing of book earnings, because it allows the transfer of taxable income across periods. Formally, we write the conformity constraint as follows:

$$
A\left[S_{B}-S_{T}\right]=0 .
$$

\subsection{Optimal Real Decisions}

\subsubsection{Without accounting considerations-the standard economics approach}

To analyze the interaction between real and accounting considerations, we next introduce a continuous real decision, $\mathrm{D}$, made by the firm in the first period. This decision could be the purchase of a capital good, a decision to undertake research and

\footnotetext{
${ }^{20}$ Note that imposing this constraint is equivalent to specifying that $\Omega$ goes to infinity whenever $S_{T}$ and $S_{B}$ diverge.

${ }^{21}$ Technically, the A variable concerns what one might call "marginal conformity," i.e., whether shifts from baseline "unmanipulable" measures of book and tax income must be equal. This is a different concept than "partial conformity," which refers to the fact that some aspects of accountings are the same for tax and book purposes, and some are not.
} 
development, where to locate a plant, how to finance capital, or any number of decisions that a firm must make. This decision will determine the firm's cash flows and the discretion available to the firm. In the remainder of this section, we demonstrate how accounting considerations influence the optimal choice of D, given that D may affect the amount of discretion available to the firm.

In the interest of building intuition, rather than immediately analyzing the general case, we begin by describing the optimal choice of $\mathrm{D}$ when there are no financial accounting considerations and no shifting choices. In this case, D determines cash flows and, in turn, determines tax obligations.

To characterize the effects of taxes on real and accounting decisions, we derive the first-order conditions that characterize an optimal choice. By examining first-order conditions we are assuming that each real decision (and, below, the shifting decisions) is a continuous variable. We presume that the optimal decision is an interior solution (i.e., it is non-zero), and so the firm should pursue this activity until its marginal contribution to firm value, $\mathrm{M}$, is zero. If $\mathrm{D}$ were a lumpy, rather than a continuous, decision, the firstorder (equality) conditions that follow can be thought of as inequalities that dictate the optimal yes-or-no decision: if and only if the left-hand side (the decision's contribution to M) exceeds zero should the firm "do" D.

If neither book income, discretion, nor conformity is of concern, then the firstorder condition simplifies to something familiar to economists: D should be set so that at the margin the present value of after-tax revenues equals zero.

$$
\sum_{j} \frac{\partial C_{j}^{1}}{\partial D}+\delta \sum_{j} \frac{\partial C_{j}^{2}}{\partial D}-\sum_{i} \sum_{j}\left[T^{1^{\prime}} \frac{\partial Y_{T}^{1}}{\partial C_{j}^{i}}+\delta T^{2^{\prime}} \frac{\partial Y_{T}^{2}}{\partial C_{j}^{i}}\right] \frac{\partial C_{j}^{i}}{\partial D}=0
$$

For functions with a single argument, a prime indicates the first derivative of that function with respect to its argument, so that $T^{i^{\prime}}$ is the marginal tax rate in period $i$, defined as the change in tax liability due to a marginal change in taxable income. The first two summations are just the marginal change in the pre-tax cash flows, summed over all categories, in each period. The value of these cash flows is eroded by the additional tax obligations that they trigger, i.e., the marginal increase in total discounted present 
value of tax liabilities. A marginal increase in cash, e.g. $\left(\frac{\partial C_{j}^{1}}{\partial D}\right)$, triggers a change in taxable income $\left(\frac{\partial Y_{T}^{1}}{\partial C_{j}^{1}}\right)$. This increase is multiplied by the marginal tax rate $\left(T^{1^{\prime}}\right)$ to determine the change in tax obligation. Note that, because the model is based on a set of cash flow categories, this framework allows that the tax obligations triggered by two actions that generate the same total pre-tax cash flow in each period need not be the same.

\subsection{2.}

\subsubsection{When book income matters}

When managers care about book income as well as real cash flows, the marginal value of any decision depends not only on how it affects after-tax cash flows, but also on how it affects book income in both periods. It becomes possible that a corporation will want to undertake a marginal real activity even if it reduces the present value of after-tax cash flows. To pursue this idea, we introduce the concept of a "marginal value" (MV) to capture this value in a parsimonious way, and so define the following expressions:.

$$
\begin{aligned}
& \mathrm{MVC}_{j}^{1}=M_{1}+M_{2} \frac{\partial Y_{B}^{1}}{\partial C_{j}^{1}}+\delta M_{3} \frac{\partial Y_{B}^{2}}{\partial C_{j}^{1}} \\
& \mathrm{MVC}_{j}^{2}=\delta M_{1}+M_{2} \frac{\partial Y_{B}^{1}}{\partial C_{j}^{2}}+\delta M_{3} \frac{\partial Y_{B}^{2}}{\partial C_{j}^{2}} \\
& \mathrm{MVT}^{1}=M_{1}+M_{2} \frac{\partial T_{B}^{1}}{\partial T^{1}}+\delta M_{3} \frac{\partial T_{B}^{2}}{\partial T^{1}} \\
& \mathrm{MVT}^{2}=\delta M_{1}+M_{2} \frac{\partial T_{B}^{1}}{\partial T^{2}}+\delta M_{3} \frac{\partial T_{B}^{2}}{\partial T^{2}}
\end{aligned}
$$

Each MV term takes into account the marginal value to the firm of both the cash flows and book income in each period, through the $M_{i}$ terms. Recall that $M_{1}, M_{2}$ and $M_{3}$ are the derivatives of the objective function $M($.$) with respect to, respectively, each of its$ three arguments (the present-value of real after-tax cash flows, period 1 after-tax book income, and (discounted) period 2 after-tax book income). ${ }^{22}$ For example, the MV of an

\footnotetext{
${ }^{22}$ Note that $M_{1}, M_{2}$ and $M_{3}$ are functions, not scalars. The marginal value of each of the three arguments of the $\mathrm{M}($.$) function may depend on the level of the other arguments.$
} 
increase in cash flow from category $j$ in period 1 is the value of the cash flow $\left(M_{1}\right)$, plus the marginal increase in period 1 book income multiplied by the marginal value of period 1 book income $\left(M_{2}\right)$, plus the analogous (discounted) term for period 2 book income.

When the firm is concerned with book income as well as real cash flows, the firstorder condition for the optimal D will reflect that a marginal change in D adds (or subtracts) value through its effect on after-tax book income. Using the MV notation, we can write the first-order condition in this more general case as follows:

$$
\begin{aligned}
& \sum_{j}\left[\mathrm{MVC}_{j}^{1}\right] \frac{\partial C_{j}^{1}}{\partial D}+\sum_{j}\left[\mathrm{MVC}_{j}^{2}\right] \frac{\partial C_{j}^{2}}{\partial D} \\
& -\sum_{i} \sum_{j}\left[\mathrm{MVT}^{1}\right] T^{1^{\prime}} \frac{\partial Y_{T}^{1}}{\partial C_{j}^{i}} \frac{\partial C_{j}^{i}}{\partial D}-\sum_{i} \sum_{j}\left[\mathrm{MVT}^{2}\right] T^{2^{\prime}} \frac{\partial Y_{T}^{2}}{\partial C_{j}^{i}} \frac{\partial C_{j}^{i}}{\partial D}=0
\end{aligned}
$$

This optimality condition generalizes the standard case shown in equation (16) because it recognizes that changes in book income affect the firm's objective to the extent that book income has marginal value in each period. If, for example, book income has a higher value in period 1 than in period 2, then $\mathrm{M}_{2}$ exceeds $\delta \mathrm{M}_{3}$ and the effect of $\mathrm{D}$ on the timing of book income affects the attractiveness of $\mathrm{D}$.

As in the standard case, the value of additional cash is eroded by the tax system. Tax obligations are increased by the marginal tax rate multiplied by the marginal increase in taxable income triggered by the rise in cash, $T^{1^{\prime}} \frac{\partial Y_{T}^{1}}{\partial C_{j}^{i}} \frac{\partial C_{j}^{i}}{\partial D}$. The marginal cost to the firm of an increase in tax obligations is the MV of taxes in that period, which includes both the marginal value of real discounted cash flow $\left(M_{1}\right)$ and the marginal value of book income multiplied by the reduction in book income resulting from the change in the tax liability in each period $\left(M_{2} \frac{\partial T_{B}^{1}}{\partial T^{1}}\right.$ and $\left.\delta M_{3} \frac{\partial T_{B}^{1}}{\partial T^{1}}\right)$.

The expanded optimality condition highlights the mechanics of the tax system. As in the standard case, a choice D that generates cash flow is less valuable if it also triggers a required payment to the IRS. The expanded optimality condition demonstrates that the total cost to the firm of paying the IRS is not just the amount of the check. The 
increased payment to the IRS must be accounted for in the firm's financial statements. This implies that book income will be lowered, and the value of this to the firm will depend on when the tax must be booked and the marginal value of book income in that period.

\subsubsection{Discretion and shifting}

Unlike in the standard economics model, the choice of $D$ may affect the constraints $\overline{S_{T}}, \overline{S_{B}}$, and $\overline{P_{B}}$, which determine how much shifting the firm is able to accomplish. By assumption, shifting incurs no cost up to the constraint, and is impossible beyond the constraint. If a firm wants to shift more than the constraint, it must undertake other activities $(D)$ that produce additional slack. As a result, real decisions may add value (i.e., increase $M$ ) by expanding the scope of discretion. ${ }^{23}$ Thus, the model highlights the link between real activities and tax and book manipulation because, to the extent that shifting has value, it may affect the real decision $D$.

The assumption that shifting is free up to a point, given the actions $\mathrm{D}$, and impossible beyond that is consistent with a firm choice that creates a tax obligation that must be met at some point, and firms may move that obligation backwards or forwards, but they can do this only up to some amount. If a firm values discretion at the margin, then the optimal amount of a decision $\mathrm{D}$ that raises discretion will be higher than it would be absent concerns about timing and discretion. Equivalently, we can say that the cost of capital for capital goods that produce (valuable) discretion is lower than it is for capital goods with the same cash-flow implications that do not create discretion. Formally, the first-order condition for D becomes:

\footnotetext{
${ }^{23}$ Recall that our reduced-form version of the manager's objective function rules out the possibility that expanding discretion may itself affect the objective function of managers by, for example, reducing the relative value of book income versus cash flows because the market becomes more suspicious of the information content of earnings figures. Fischer and Verrecchia (2000) and Stocken and Verrechia (2004) address similar issues.
} 


$$
\begin{aligned}
& \sum_{j}\left[\mathrm{MV} C_{j}^{1}\right] \frac{\partial C_{j}^{1}}{\partial D}+\sum_{j}\left[\mathrm{MV} C_{j}^{2}\right] \frac{\partial C_{j}^{2}}{\partial D} \\
& -\sum_{i} \sum_{j}\left[\mathrm{MV} T^{1}\right]^{I^{\prime}} \frac{\partial Y_{T}^{1}}{\partial C_{j}^{i}} \frac{\partial C_{j}^{i}}{\partial D}-\sum_{i} \sum_{j}\left[\mathrm{MVT}^{2}\right] T^{2^{\prime}} \frac{\partial Y_{T}^{2}}{\partial C_{j}^{i}} \frac{\partial C_{j}^{i}}{\partial D} \\
& +\lambda_{T}{\overline{S_{T}}}^{\prime}+\lambda_{B}{\overline{S_{B}}}^{\prime}+\lambda_{P}{\overline{P_{B}}}^{\prime}=0
\end{aligned}
$$

If a real decision affects discretion by relaxing the constraints on shifting, then ${\overline{S_{T}}}^{\prime},{\overline{S_{B}}}^{\prime}$, and ${\overline{P_{B}}}^{\prime}$ will be non-zero and will affect the real decision as long as the associated $\lambda$ value is non-zero. Formally, the $\lambda$ terms are the Lagrange multipliers on the shifting constraints in the constrained maximization problem the company solves. Informally, $\lambda_{T}, \lambda_{B}$, and $\lambda_{P}$ are equal to how much more $M$ could be achieved if the taxable income, book income, and book tax provision shifting constraints, respectively, were to be relaxed by one dollar. Henceforth we will refer to the $\lambda$ terms as the "value" of relaxing the shifting constraints.

If a shifting constraint is not binding, so that the firm is not shifting all that it could, then the relevant $\lambda$ term is zero: the constraint imposes no cost on the firm, and thus relaxing the constraint has no value. When it is binding, $\lambda$ is positive and equal to the value of moving income between periods. Thus, for example, the term $\lambda_{B}{\overline{S_{B}}}^{\prime}$ is zero when the constraint on the shifting of income for book purposes is not binding, but when it is binding, it is equal to the value of relaxing the constraint by one dollar, which is equivalent to the value of moving book income between periods, multiplied by how much the real decision relaxes the constraint. In the next section, we expand on what determines the values of the $\lambda$ terms when we focus on the shifting and conformity constraints as well as the cost of divergence.

\subsubsection{Conformity}

It is worth noting that the first-order condition for optimal $D$ contains no term that directly relates to a conformity requirement because $D$ does not relax (or tighten) the conformity requirement the way we allow it to relax or tighten the shifting constraints. This does not, however, imply that conformity has no effect on real decisions; indeed, the 
opposite is true. Imposing conformity can change the real decision calculus by changing the value of discretion, which is captured by the $\lambda_{T}, \lambda_{B}$, and $\lambda_{P}$ terms.

Consider, as an example, a real decision that relaxes the constraint on book income shifting. If the constraint is otherwise binding, this makes the real decision more attractive than otherwise. Now impose conformity, and assume that the optimal response to conformity is for the firm to reduce how much taxable income it shifts to the second period and reduce how much book income it shifts to the first period. Moreover, suppose that the fall in book income shifting implies that the book income shifting constraint is no longer binding. Under conformity, the fact that the real decision relaxes the book income shifting constraint has no value ( $\lambda_{B}$ falls from a positive number to zero), and the real decision is less attractive than it was in the absence of conformity.

\subsection{Optimal shifting, with real consequences}

Not only do accounting considerations affect real decisions, but real decisions also affect shifting decisions. Indeed, in our model the two sets of decisions are simultaneously determined. We now examine the shifting decisions.

\subsubsection{Taxable income shifting}

Consider first the shifting of taxable income. The first-order condition that characterizes optimal taxable income shifting can be written as follows:

$$
\left[\mathrm{MV} T^{1}\right] T^{1^{\prime}}-\left[\mathrm{MV} T^{2}\right] T^{2^{\prime}}+\left[M_{1}+M_{2}-\left[\mathrm{MV} T^{1}\right] T^{1^{\prime}}\right] \Omega^{\prime}-\lambda_{T}-\mu A=0
$$

where recall that $\lambda_{T}$ is the marginal value of the taxable income shifting constraint. Equation (20) introduces a new term, denoted $\mu$, which is equal to the marginal value of the conformity constraint: how much greater $M$ could be if taxable income and book income shifting could diverge by one dollar. ${ }^{24}$

It is helpful to consider some special cases. First, assume that there are no divergence costs $\left(\Omega^{\prime}=0\right), \lambda_{T}$ is zero, and conformity is not relevant $(\mu A=0)$. In this case the first-order condition becomes $\left[\mathrm{MV} T^{1}\right] T^{1^{\prime}}=\left[\mathrm{MV} T^{2}\right] T^{2^{\prime}}$, which implies that the (cash

\footnotetext{
${ }^{24}$ Formally, $\mu$ is the Lagrange multiplier on the conformity condition.
} 
flow and book income) implications of reporting an additional dollar of taxable income in each period must be equal; if they are not, then taxable income should be shifted. This equality may not hold because a firm faces a different marginal tax rate in the two periods $\left(T^{1^{\prime}} \neq T^{2^{\prime}}\right),{ }^{25}$ However, note that taxable income shifting can be valuable even if the marginal tax rates are equal in both periods, if the (cash flow and book income) value of a dollar of tax payments is not equal in the two periods $\left(\left[\mathrm{MVT}^{1}\right] \neq\left[\mathrm{MV} T^{2}\right]\right)$.

Next, consider the case in which shifting is limited, so that $\lambda_{T}$ is not zero. Then, $\left[\mathrm{MV} T^{1}\right] T^{1^{\prime}}-\left[\mathrm{MV} T^{2}\right] T^{2^{\prime}}=\lambda_{T}$, which means that the (book-income-adjusted) tax arbitrage is incomplete. Because of the constraint on shifting, there may be a gain from having taxable income in one period that the firm cannot take advantage of. This reminds us that $\lambda_{T}$ is the value of being able to shift an additional dollar of taxable income between periods (or, equivalently, of the marginal cost of not being able to shift).

Finally, the relationship between the optimal $S_{B}$ and the firm's choice of $S_{T}$ is implicit in this optimality condition. The two types of shifting interact through the $\mu$ and $\Omega$ terms. When $A=1$ (conformity is required), $\mu$ will be non-zero, but $\Omega$ will be zero, because the book income shifted equals the taxable income shifted.

When $\Omega^{\prime} \neq 0$, then the effect of taxable income shifting on the cost of divergence matters. A marginal increase in $S_{T}$ may cause $\Omega$ to rise or fall, depending on whether or not $S_{T}$ is smaller than or larger than $S_{B}$, before the increase in $S_{T}$. An increase in the cost of divergence lowers total cash flow and period one book income. It also lowers taxes paid because this cost is, by assumption, tax deductible. ${ }^{26}$

\footnotetext{
${ }^{25}$ Although not explicitly in this model, in reality this could occur because of the limited refundability of net operating losses. The present value of the additional tax liability caused by an additional dollar of taxable income is the concept that, e.g. Graham and Mills (2006) and others have tried to measure quantitatively using data from financial statements and corporate tax returns, usually referred to as the marginal tax rate. This is quite different than what tax economists call the marginal effective tax rate on an incremental dollar of investment, which is the accrual-equivalent tax rate triggered on the returns to a marginal investment, which depends not only on the statutory tax rate but also the pattern of depreciation allowances. Fullerton (1984) provides a helpful discussion of this concept. Although economists often ignore this in their calculations (although see, e.g., Auerbach (1986)), in principle the marginal effective tax rate should depend on the details of limited loss refundability that are central to the marginal tax rate calculations done by accounting and finance scholars (e.g., Scholes, and Wolfson (1992) and Graham (1996).

${ }^{26}$ Almost all divergence costs are deductible, e.g., legal fees and increased borrowing costs. One divergence cost that is not deductible is additional Federal taxes that could arise from an IRS audit.
} 
In either case, whether $\Omega^{\prime} \neq 0$ or $\mu A \neq 0$, the optimal $S_{T}$ will be linked to the firm's choice of $S_{B}$. The tension created will prevent the (book-income-adjusted) tax arbitrage from being executed fully. For example, suppose that the firm would like to move a large amount of book income to the first period, but would like to defer taxable income to the second period. In such a case, the firm may choose to set $S_{T}$ lower than is optimal from the point of view of reducing total discounted taxes paid, because doing so allows the movement of more book income to the first period. This is one example of how tax minimization is not generally an optimal strategy.

\subsubsection{Book income shifting}

The first-order condition with respect to book income shifting is

$$
-M_{2}[1-\tau]+\delta M_{3}[1-\tau]-\left[M_{1}+M_{2}-\left[\mathrm{MVT}^{1}\right] T^{1^{\prime}}\right] \Omega^{\prime}-\lambda_{B}+\mu A=0
$$

Firms may wish to move book income because they value discounted book income in one period more than in another, in which case $M_{2}-\delta M_{3} \neq 0$. If $\Omega^{\prime}=\lambda_{B}=\mu=0$, then book income is shifted until the marginal value of discounted after-tax book income is equal across periods. If $M_{2}=M_{3}$, the only motivation for shifting book income is that firms would prefer to report earnings sooner, due to discounting. Note also that moving one dollar of book income across periods moves only $1-\tau$ dollars of after-tax book income.

If the constraint on book shifting is binding, then $\lambda_{B}$ is positive and the marginal contribution to $M$ of shifting through its effect on book incomes, $-\left(M_{2}-\delta M_{3}\right)(1-\tau)$, will be greater than zero by $\lambda_{\mathrm{B}}$; the constraint limits the amount that the firm wants to shift.

There are several similarities between the optimality conditions for $S_{B}$ and $S_{T}$. The terms related to $\mu$ and $\Omega$ are exactly the same, with a change in sign, between the equations. This is because, at any given point, an increase in $S_{B}$ must have exactly the opposite effect of an increase in $S_{T}$ on the cost of divergence.

Note also that, when $\mu \neq 0$, and marginal conformity is imposed, either $\lambda_{T}$ or $\lambda_{B}$ must be equal to zero. This is because, when the two shifted amounts are forced to be the same, only one of them can be binding. Thus, of the three values, $\lambda_{T}, \lambda_{B}$, and $\mu$, one of them is always zero. 
There are two reasons that the choice of $S_{T}$ and $S_{B}$ are not independent: conformity and the cost of divergence. If conformity is an issue $(A=1)$, then shifting of either taxable (book) income may become more or less attractive, depending on whether it aids or hinders book (taxable) income. Whenever $S_{T}$ and $S_{B}$ would not be equal in the absence of conformity, the conformity condition binds, and the value of $\mu$ is non-zero. When neither shifting constraint is binding, conformity means that at least one type of shifting will have to change; if both change, they will change in opposite directions. This is reflected by the fact that the $\mu A$ terms enter the first-order condition for $S_{T}$ and $S_{B}$ with opposite sign. If conformity puts upward pressure on $S_{T}$, then adding the $\mu A$ term means that the marginal contribution to the discounted value of cash flow will just equal minus one times the value of the conformity constraint, so that the marginal tax saving is actually negative.

Conversely, if conformity puts downward pressure on book income shifting, the marginal contribution to the value of book income will be equal to the (positive) value of the conformity constraint, so that at the margin there would be additional value from booking income, if not for the conformity constraint. If both the shifting and conformity constraints are binding, (so that absent any constraints $S_{T}$ and $S_{B}$ would be different and at least one would exceed the shifting limit), both the $\mu$ and (at least one) $\lambda$ terms are relevant.

If divergence between tax and book income is costly $\left(\Omega^{\prime} \neq 0\right)$, then optimal shifting of both tax and book must account for the fact that shifting book or tax items without shifting the other item will affect the amount of book-tax differences and change the cost of such divergence. Note that the two bracketed terms that involve $\Omega$ appear in an equal, but differently signed, way in the two first-order conditions. That reflects the fact that if increasing $S_{T}$ has a marginal divergence cost, then decreasing $S_{B}$ must have the same marginal cost.

\subsubsection{Shifting the book tax provision}

The firm's optimization problem involves one final choice, the shifting of the book tax provision, $P_{B}$. The first-order condition for this choice is very simple:

$$
M_{2}-\delta M_{3}-\lambda_{P}=0
$$


When a firm increases $P_{B}$ (i.e., moves a dollar of book tax provision to the second period), it directly transfers one dollar of after-tax, book income from the second period to the first period. The firm will shift the provision in this manner until after-tax book income is equally valuable across periods, unless it is constrained in the amount of available discretion.

Note that this choice will interact with the other shifting decisions. If a firm has considerable discretion in timing the book tax provision, it may use this discretion to equalize the value of after-tax, book income over time. This lowers the value of shifting pre-tax book income.

When conformity between $S_{T}$ and $S_{B}$ is binding (or divergence is very costly), shifting of the book tax provision may enable the firm to circumvent the conformity constraint. Consider a firm that would like to move taxable income into the second period, but places a high marginal value on after-tax book income in the current period. Under conformity, the firm cannot use its discretion to do both. If this firm has considerable discretion in the timing of its book tax provision, however, it could move taxable income into the second period, along with a matching amount of book income, and then offset the loss of pre-tax book income in the first period by reducing $P_{B}$ in the first period.

Note that the substitutability of shifting book income and changing the timing of the book tax provision assumes that the benefits to managing after-tax earnings, using the book tax provision, are the same as shifting (an after-tax equivalent amount of) pre-tax earnings. The findings in Robinson (2006) challenge this assumption. In her study of investments in housing tax credits, she finds that firms value pre-tax earnings more than reductions in the book tax provision. If her findings generalize, then firms may have to shift larger amounts of book tax provision to reduce financial reporting costs the same as with a smaller portion of book income shifting. Her findings are consistent with analysts and others using operating earnings, EBITDA, or similar measures that ignore the book tax provision to value a firm.

\subsection{Summary}


The formal analysis of this model suggests that the attractiveness of a real decision depends on both its effect on discounted after-tax cash flow and its effect on book income. A key result is that the attractiveness of a real decision depends on whether it expands the discretion of both book and tax accounting. If the real decisions of the firm affect the discretion the firm has in timing its taxable income, pre-tax book income, and book tax provision, then tax payments and book income may be moved to periods when it is of maximum value to the firm. Discretion has value because if certain business operations induce a firm to show particularly high or low book income in a period, the firm may want to smooth its earnings through discretionary book accruals. Likewise, if normal business operations lead to different marginal tax rates, perhaps through net operating losses, then an ability to shift taxable income will become important. However, real decisions that provide discretion lose value if the real decision leads to a costly divergence between pre-tax book income and taxable income.

\section{Examples of the Value of Discretion}

This section provides examples that illustrate how taxes affect real and accounting choices using the integrative framework detailed above. In each case, we see the value created by a real decision that provides book and/or tax discretion. We also see that firms that value discretion, at the margin, will have incentives to make real decisions that increase their flexibility in reporting for both book and tax purposes. In the first example, incentives to increase book and tax discretion encourage firms to extend more credit than would otherwise be optimal. In the second example, the decision to operate in a low-tax country provides book discretion. In the third example, activities that result in uncertain tax positions (e.g., the transfer prices of intercompany sales) create book discretion. The fourth example examines tax shelters, transactions that create unusually high levels of tax discretion.

\subsection{Incentives to Extend Credit}

The first example of the value of discretion involves incentives to extend credit. Consider a firm with $\$ X$ in cash sales and $\$ Y$ in credit sales. Further assume that, after considering that some of the credit sales will not be collected, collection costs and the 
time value of money, the present value of the $\$ Y$ of credit sales equals $\$ X$. That is, the expected present value of the credit sales equals the value of the cash sales.

If the firm would benefit from the ability to manage its earnings, then the discretion provided by the credit sales makes them more valuable to the firm than the cash sales. The reason is that, at the time of the sale, the firm must estimate the uncollectible receivables and accrue (i.e., report as a current expense) the anticipated bad debts. Because estimates are, by definition, imprecise, firms have some leeway in the amount that they record for bad debts. If they wish to shift some income to (from) this year from (to) future years, they can lower (increase) the estimate of bad debts this year, within reason, and then record higher (lower) bad debt expenses in future years. In terms of the model, the bad debt reserve for book purposes raises $\overline{S_{B}}$.

Moreover, if the firm would benefit from the ability to manage its taxable income, then the discretion provided by the credit sales makes them more valuable for tax purposes to the firm than the cash sales. The reason is that firms cannot deduct their bad debts at the time of the sale. Instead, they must wait until a specific receivable is deemed worthless. However, determining when a receivable becomes worthless is a judgment call. This element of judgment provides the taxpayer with valuable discretion in the timing of the deduction, i.e., credit sales provide the firm some leeway in recording a tax deduction. In terms of the model, investments that produce write-offs generate discretion in the timing of real taxes, increasing $\overline{S_{T}}$. Because credit sales provide potentially important discretion in recording transactions for book and tax purposes, we would anticipate that some firms would advance credit at a lower cost than would be otherwise optimal.

In addition to the usual incentive to accelerate deductions for tax purposes (represented by the $\delta$ term in the model), the tax discretion provided by credit sales may be valuable when net operating losses or credits are expiring. In the model, loss or credit expiration is a reason why marginal tax rates may vary across periods $\left(T_{0}^{\prime} \neq T_{1}^{\prime}\right)$. To the extent that write-offs are associated with unprofitable ventures (e.g., a firm's profitability is inversely correlated with bad debts), this discretion is ex ante particularly valuable, because it reduces the probability of being in a net operating loss position. By timing the write-offs of receivables, the company may be able to maximize the tax savings from 
both operational losses and write-offs; they also gain discretion in the recognition of book income. Because the timing for tax and book purposes must be the same, the value of discretion depends on the values of both shifting constraints, $\lambda_{B}$ and $\lambda_{T}$. The added discretion implies that high-risk ventures (e.g., banks lending to developing countries) are more attractive than otherwise for those companies for which either tax and/or book discretion has value. ${ }^{27}$

\subsection{Incentives to invest abroad}

The next example of the value of discretion involves the incentive to invest outside the U.S. Although foreign subsidiaries of U.S. companies pay income tax in the jurisdictions where they operate, their parent companies generally do not pay any U.S. taxes on these foreign earnings until the profits are repatriated as dividends, at which time they pay the U.S. tax due net of any applicable foreign tax credit for taxes paid to the foreign government (sometimes called the "residual" U.S. tax). If the profits are never repatriated, no U.S. taxes are ever paid.

For book purposes, firms must record the profits of their foreign subsidiaries in the period when they are earned. ${ }^{28}$ Managers, however, have a choice about when to record the book tax provision related to the U.S. tax triggered by repatriation. One option is to estimate the eventual U.S. tax and expense those taxes when the foreign profits are booked. By matching the tax provision to the foreign earnings, this option lowers current after-tax earnings, but leaves after-tax earnings unaffected when the dividend is paid.

If the firm does not expect to repatriate the profits in the foreseeable future, there is a second option. The firm can defer the expense until they decide to repatriate the funds. If they never repatriate, then they never provide for the U.S. taxes. This approach results in higher after-tax earnings in the year that the foreign profits are earned (because profits are not reduced by an estimate of the U.S. taxes at repatriation). It also results in a

\footnotetext{
${ }^{27}$ There may, of course, be general equilibrium price effects that dampen the effects we have been discussing. For example, if the supply of these assets is not perfectly elastic, the increased demand for high-risk ventures may increase their relative price, dampening but not eliminating the enhanced attractiveness the book and tax discretion offers.

${ }^{28}$ An important distinction between book and tax is that the financial statements include the activities of all foreign subsidiaries, while the tax return generally excludes the profits of foreign subsidiaries.
} 
higher book tax provision (and lower after-tax book earnings) in the period when the firm decides to repatriate the foreign profits.

Because a firm can change its intentions about paying a dividend at any time, it can shift book income over time. Furthermore, a firm may decide that profits whose U.S. tax provision has already been booked will not be repatriated after all. If so, the tax expense that was booked for the U.S. tax in the past is removed from the books, shifting book income into that year.

This discretion in financial reporting provided by foreign operations means that firms have an incentive to locate in low-tax countries, e.g., tax havens. The reason is that generally the less the foreign tax, the greater the U.S. tax, and thus the larger the book tax provision that can be shifted across periods. Thus, GAAP encourages investment in tax havens. In terms of the model, investing in tax havens raises $\overline{S_{B}(D)}$.

To summarize, the tax policy of deferring the U.S. tax liability on the earnings of foreign subsidiaries provides the parent company with potentially valuable discretion in financial reporting. Because the U.S. tax payment is deferred until repatriation, firms can expense the tax when the profits are earned or whenever they decide that they will repatriate the funds. This discretion provides an incentive to invest in low-tax countries. The discretion would be eliminated if deferral of the residual U.S. tax was repealed or a territorial system was adopted. ${ }^{29}$

In 2004, the book discretion arising from the tax law came full circle. The American Jobs Creation Act of 2004 provided a tax holiday to U.S. companies that repatriated earnings from their foreign subsidiaries. The amount of foreign earnings that enjoyed a reduced tax rate was limited to the amount of "permanently reinvested foreign earnings," an accounting term for the amount of profits in foreign subsidiaries for which the firm has not recorded a residual U.S. book tax provision ${ }^{30}$ In other words, the tax holiday was limited by the way that the managers booked the tax law's deferral of U.S. taxes.

\footnotetext{
${ }^{29}$ See Collins, Hand and Shackelford (2001) and Krull (2004) for details about permanently reinvested foreign earning. Krull (2004) presents evidence of their use to manage earnings.

30 "Permanently" does not mean "never;" rather, it means that the firm does not intend to pay the dividend in the "foreseeable" future.
} 
This example demonstrates the intersection and joint determination of a real decision (where to locate operations), a tax and financial decision (when to repatriate), and a book decision (when to record the book tax provision related to the repatriation). By investing abroad, the firm gains valuable tax and book discretion. By timing the repatriation, the firm gains valuable tax and book discretion and manages its global cash balance.

The model of Section 3 formalizes the idea that the incremental discretion in the timing of the book tax provision provides an incentive for some firms to invest in low-tax countries. The lower the foreign tax rate, the larger the residual tax in the U.S. and consequently, the greater the earnings management potential. This type of foreign investment, in addition to the contribution to real earnings, increases $\overline{S_{B}}$, which has expected value depending on the situation of the firm; equivalently, one can think of the increased book discretion as reducing the effective cost of capital for this type of investment.

\subsection{Uncertain tax positions, e.g., transfer pricing}

The third example of discretion involves uncertain tax positions that give rise to book discretion. Although many transactions involve legal and factual ambiguity, we focus on intercompany transfer pricing within a multinational corporation. As noted in the preceding section, financial statements are reported on a worldwide consolidated basis, but tax returns generally exclude profits earned through foreign subsidiaries. Thus, multinationals can lower worldwide taxes by strategically setting their intercompany transfer prices, for example by having corporations located in high-tax countries buy at a high price and sell at a low price when trading with affiliated corporations in low-tax countries.

Taxing authorities in high-tax countries attempt to defend their tax bases by establishing transfer pricing rules that constrain this type of cross-country income shifting, and there is a continual cat-and-mouse game between multinationals and the taxing authorities over transfer pricing. The most difficult transfer prices involve intangibles whose value is difficult to establish (e.g., brand names) and whose taxable income can be easily shifted. Thus, tax minimization opportunities for transfer pricing 
are greatest among multinationals with high profit margins from intangibles, e.g., research and development. The classic example is the pharmaceutical industry.

The tax uncertainties associated with these companies provides some book discretion. Since transfer prices are very difficult to establish and subject to continual scrutiny by taxing authorities around the globe, it is very difficult to estimate the eventual worldwide taxes that will be paid, following possible audits in multiple jurisdictions. Thus, companies typically accrue a liability for the uncertainty surrounding transfer prices. Over time, resolution is reached about the tax liability, albeit sometimes years later. In the meantime, the uncertainty surrounding the eventual resolution of the tax liability gives the company some leeway is estimating its book tax provision. This is sometimes referred to as "cushion." Historically it has been viewed as an important means of managing earnings (Dhaliwal, Gleason and Mills, 2004; Blouin and Tuna, 2006).

To summarize, engaging in transactions that inherently result in uncertainty about the tax liability provides not only tax discretion (e.g., the ability to use transfer prices to shift income from high-tax countries to low-tax countries), but also provides book discretion. Thus, investments in intangibles that can cross jurisdictions carry the added benefit of facilitating both tax and earnings management.

\subsection{Tax shelters}

In the absence of book income concerns, in this framework a firm should pursue any activity that affects multiple categories of cash flows such that the present discounted value of the sums of those after-tax cash flows increases. Ths applies to shifting from taxable to tax-exempt bonds when the implicit tax rate on the tax-exempt bonds is less than the explicit tax rate on taxable bonds; in this case the shift would lower pre-tax income but reduce the effective tax rate by even more. It also applies to complicated "pure" tax shelters that lower the present discounted value of tax payments but leave the present discounted value of pre-tax cash flows unaffected. If book income matters, either because of divergence costs, or per se (i.e., $\mathrm{M}_{2}$ and/or $\mathrm{M}_{3}$ are non-zero), then a given tax shelter becomes less attractive to the extent that it reduces after-tax book income in an attempt to reduce taxable income. Thus, some commentators have argued that the 
"perfect" tax shelter also either increases, or leaves unaffected, after-tax book income (see Weisbach, 2002). Of course, conformity would eliminate both the pure and the perfect tax shelter because any reduction in taxable income would cause an equivalent decline in book income. Whether the firm could successfully signal, outside of standard financial accounting, that the book earnings understate "true" earnings, is another question.

Tax shelters also are used to boost current book earnings even if there is no reduction in actual current tax payments. As discussed above, a book tax provision is recorded when transactions result in future tax payments. Thus, a firm may undertake a tax shelter that reduces future tax payments, but has no effect on current tax liabilities, perhaps because the firm has net operating loss carryforwards. If so, its book tax provision will fall, increasing current book earnings, but its current tax liability will be unaffected. $^{31}$

5.

\section{Policy}

The effect of tax changes that are equivalent in the standard economic model may not be the same when accounting considerations enter. Ignoring these book considerations can lead economists to be surprised both at the behavioral response to tax policy and at the policies that business interests favor. As an example of the latter,

\footnotetext{
${ }^{31}$ Such "book" tax shelters reportedly were common at Enron in the late 1990s. The Joint Committee on Taxation's 2003 study following the company's collapse states that:

"Although providing financial accounting benefits, the early structured transactions, including the commodity prepay transactions, were primarily engaged in for Federal income tax benefits. However, as Enron began to report losses for Federal income tax purposes, the importance of immediate tax deductions declined. At the same time, the importance of financial accounting income to Enron increased. As a result, Enron's focus shifted from structured transactions that could shelter specific tax items to transactions that could generate financial accounting benefits.

"Arguably, the primary reason for engaging in most of the subsequent structured transactions after 1996 was for the financial accounting benefits they generated rather than the Federal income tax benefits. Indeed, many of the structured transactions were designed to permit Enron to begin reporting the financial accounting benefits of a transaction immediately even though the Federal income tax benefits (which generated the financial accounting benefit) would not occur until significantly into the future." (Joint Committee on Taxation, 2003, pp. 102-103.)
} 
consider two alternative tax policies that are designed to make investment more attractive - a decline in the corporate tax rate versus immediate expensing for tax purposes. It is clear that both a reduction in marginal tax rates and a postponement of tax payments increase the attractiveness of a real investment decision, and that there is some level of rate reduction that would have the same effect on the incentive to invest as immediate expensing (i.e., postponement of tax payments).

Neubig (2006) shows that, once financial accounting implications are considered, the lower corporate tax rate generally dominates expensing. The reason is that, even if the present values of the after-tax cash flows from the investment are identical with a rate reduction, the lower tax rate accelerates book profits. That is, the present value of book earnings is greater with a lower tax rate than with expensing. This occurs because expensing does not change the book tax provision, i.e., the reduction in book profits for past, present and future taxes. On the other hand, a lower statutory corporate tax rate immediately reduces the tax rate applied to current book profits, lowering the book tax provision. Furthermore, it lowers the tax that is expected to be levied on future tax liabilities. Thus, if the firm has more deferred (or future) tax liabilities than deferred tax assets, as is the case for most firms, then there is a further boost to earnings because the deferred tax liabilities are revalued using the new corporate tax rate and the change is included as accounting income. ${ }^{32}$ Of course, for those companies where the deferred tax assets exceed the deferred tax liabilities, the firm's book income falls with a rate reduction and thus they would be more likely to oppose a lower tax rate. ${ }^{33}$

Another current policy debate concerns conformity, i.e., the requirement that book and taxable income be the same. Firms currently report taxable income to the IRS according to tax law, and report book income to the public according to GAAP. The

\footnotetext{
${ }^{32}$ This accounting issue is reminiscent of the distinction in economic analysis between the effects of a tax change on "old capital" versus "new capital." Other things equal, the bang (i.e., increased incentive to invest) per buck (i.e., revenue lost) of an investment tax credit or accelerated depreciation exceeds that of a tax rate cut because the latter provides tax relief for income generated by past investments, which is wasted in terms of providing an incentive to future investment. The effect on the value of deferred tax assets or liabilities reflects the impact on the value of the corporation of the tax implications of past investments, or "old capital."

${ }^{33}$ The detrimental effects of a rate cut on the book earnings of certain companies in financial distress that had substantial deferred tax assets is said to have been an important reason why the tax relief for domestic manufacturing in the American Jobs Creation Act of 2004 was enacted in the form of a percentage deduction of a taxpayer's gross receipts, rather than as a rate cut.
} 
move for conformity is partly a response to the fact that these two sets of reports have been diverging in recent years, leading many analysts to conclude that firms are systematically inflating earnings and avoiding taxes. Advocates of conformity suggest that folding both systems into one would reduce the incentive to manage earnings (since taxes would be owed on any fictitious earnings), reduce tax avoidance, as well as reduce compliance costs because it eliminates the need to make two separate calculations of income. Opponents point out that book income, despite its many problems, is a strong signal of firm value to the investing public, and they are concerned that reforms might lower the quality of that signal. ${ }^{34}$

The model developed here adds a new wrinkle to this debate. Not only would conformity affect the book reporting of income and the taxable income reported to the IRS for any set of underlying real operations, it would affect these real decisions themselves. Firms will be less likely to engage in real activities that give them more discretion to report current book income if it also necessarily increases current tax payments. Whether that is a good thing or a bad thing is not obvious, though, and depends on whether or not the book income and discretion advantages of an asset move the firm's choice of $D$ away from or towards the social optimum. For example, a firm may be deciding the optimal level of investment in a foreign asset. In the absence of taxes and financial accounting concerns, the firm would choose $D^{*}$. Before considering book income or shifting, but given the lower rate of return induced by taxation, firms would choose $D^{\prime}<D^{*}$. Next, suppose that higher levels of $D$ boost book income or increase discretion in periods when that is especially valuable, . It is quite possible that the new optimum, call it $D^{* *}$, is closer to the social optimum, $D^{\prime}<D^{* *}<D^{*}{ }^{35}$ In such a case, book and discretion considerations may partially offset the distortions of the tax code, implying that financial accounting considerations move the firm towards the social optimum.

Whether or not conformity is welfare improving will depend on whether or not book considerations exacerbate or offset the distortions induced by the tax code, and we

\footnotetext{
${ }^{34}$ There are several versions of conformity that might be implemented, and we do not attempt to distinguish between them here. See Hanlon, Laplante, and Shevlin (2005) and Hanlon and Maydew (2006) for overviews.

${ }^{35}$ Of course, there is no reason to rule out the possibility that $D^{* *}>D^{*}$, or that $D^{* *}<D^{*}$.
} 
have argued that the answer to this latter question is non-trivial. Our framework is, however, only a first step in adequately addressing this question, in part because in our reduced form approach, it is impossible to make comprehensive welfare statements. If firms value book income because they are able to fool the market, then the investing public may gain from conformity, even if it pushes firms away from optimal actions in a partial equilibrium model. If book income is valued because it is a superior signal of firm value, then the information content of the economy may be damaged by conformity. Likewise, adequate analysis of the opportunity cost of investment decisions requires general equilibrium analysis. Nevertheless, we think that our framework provides fresh insight, and we hope that it will serve as a starting point for future normative analysis of policy.

\section{Conclusions}

As long as book income has value to public corporations, real decisions that facilitate book earnings management are more attractive than otherwise, and especially so to companies for which this discretion has relatively high value. Decisions that enhance the discretion of tax payments may also be more attractive than otherwise, especially to companies that face time-varying marginal tax rates. The source of this discretion may be either the accounting rules or the tax law. It is critical to know whether the book and tax accounting either must be conformed by law, or will be conformed by choice because of the private costs of maintaining separate accounting systems. When they are not conformed, divergence between the two may be costly to the extent that it alerts the IRS to possibly aggressive tax planning or the capital markets to poor earnings quality.

The formal model of this paper is offered in the hope that it will facilitate discussion of these types of issues in a rigorous, general framework. We recognize that the framework is still not general enough to capture potentially important aspects of the interaction between accounting and real decisions. For example, it does not model the underlying nature of the information asymmetry between corporate insiders and (actual and potential) shareholders to explain why book income enhances shareholder value. This may, or may not, affect the model's positive conclusions, but certainly affects its normative implications. Ideally one would like to integrate a model of the kind offered 
here with a model of the institutions that arise (e.g., performance-based executive compensation, audited financial reports, and other governance mechanisms) to address the information symmetry between shareholders and the managers of the corporation.

Nor does it place the firm's decisions within a general equilibrium setting that recognizes that tax code and accounting rule changes may affect the prices a corporation faces, and that U.S. public corporations compete against unincorporated U.S. businesses and foreign companies, including foreign multinationals. This prevents the model from addressing issues such as whether the information requirements of public corporations affect the decision of a business to be a public corporation. Nor does the model satisfactorily integrate the type of legitimate tax planning and earnings management stressed here with the use of aggressive — and possibly illegal—tax shelters, outright evasion, and fraudulent financial reporting. A similar question to the one this paper addresses arises in that context: is the gain from corporate tax avoidance inframarginal, or does it reduce the marginal tax rate on new investment? The answer depends on whether the real decision is what Slemrod (2001) calls avoidance-facilitating. If more investment (i.e., scale) enables more sheltering, then there is an implicit subsidy to investment.

Ideally, an overarching conceptual framework can help to integrate the findings of the active empirical research in this area. It would, for example, be helpful to know whether the goal of a given empirical exercise is to provide estimates of the trade-off between real and book income, and what mediates that trade-off, or whether the goal is to measure the value of an accounting constraint and how much the loosening (tightening) of the constraint reduces (increases) the effective cost of a real decision. Accomplishing that task will raise the likelihood that new research will build upon itself to produce a coherent, empirically fleshed-out picture of the interactions among the policy choices of tax and accounting regulatory authorities and the real and accounting decisions of corporations. 


\section{References}

Abarbanell, J., 2002. A framework for analyzing earnings management: Implications for stock prices, earnings and analysts' forecasts errors, Working paper, University of North Carolina.

Abarbanell, J., Lehavy, R., 2003. Can stock recommendations predict earnings management and analysts' earnings forecast errors. Journal of Accounting Research 41 (1), 1-31.

Auerbach, A. 1986. The dynamic effect of tax loss asymmetries. Review of Economic Studies 53, 205-225.

Auerbach, A., 2006. Who bears the corporate tax? In Poterba, J. (Ed.), Tax Policy and the Economy 20, National Bureau of Economic Research, MIT Press, Cambridge, MA, 1-40.

Barth, M., Beaver, W., Landsman, W., 1998. Relative valuation roles of equity book value and net income as a function of financial health. Journal of Accounting and Economics 25, 1-34.

Bird, R., 2002. Why tax corporations? Bulletin for International Fiscal Documentation 56, 194-203.

Blouin, J., Tuna, I., 2006. Tax Contingencies: Cushioning the blow to earnings? Working paper, Wharton School at the University of Pennsylvania

Collins, J., Hand J., Shackelford D., 2001. Valuing deferral: The effect of permanently reinvested foreign earnings on stock prices. In Hines, J. (Ed.), International Taxation and Multinational Activity, University of Chicago Press, Chicago, IL., 143-166.

Crocker, K., Slemrod J. Forthcoming. The economics of earnings manipulation and managerial compensation," The RAND Journal of Economics.

Crocker, K., Slemrod J. 2005. Corporate tax evasion with agency costs. Journal of Public Economics, 89(9-10), 1593-1610.

Dechow, P., Skinner, D., 2000. Earnings management: Reconciling the views of accounting academics, practitioners, and regulators, Accounting Horizons 14 (2), 235-250.

Desai, M., 2003. The divergence between book income and tax income. In Poterba, J. (Ed.) Tax Policy and the Economy 17 National Bureau of Economic Research, MIT Press, Cambridge, MA, 169-206. 
Dhaliwal, D., Gleason, C., Mills, L., 2004. Last-chance earnings management: Using the tax expense to meet analysts' forecasts. Contemporary Accounting Research 21 (2), 431-460.

Engel, E., Erickson, M., Maydew, E., 1999. Debt-equity hybrid securities. Journal of Accounting Research 37 (2), 249-274.

Erickson, M., Hanlon, M., Maydew, E., 2004. How much will firms pay for earnings that do not exist? Evidence of taxes paid on allegedly fraudulent earnings. The Accounting Review 79 (2), 387-408.

Fischer, P. and Verrecchia, R. 2000. Reporting bias. The Accounting Review. 75 (2), 229-245.

Frank, M., Rego, S., 2006. Do managers use the valuation allowance account to manage earnings around certain earnings targets? Journal of the American Taxation Association.

Fullerton, D. 1984. Which effective tax rate? National Tax Journal 37 (1), 23-41.

Gleason, C., Mills, L., 2002. Materiality and contingent tax liability reporting. The Accounting Review 77 (2), 317-342.

Graham, J., 1996. Debt and the marginal tax rate. Journal of Financial Economics 41, 4173.

Graham, J., 2003. Taxes and corporate finance: A review. Review of Financial Studies $16,1074-1128$.

Graham, J., Harvey, C., Rajgopal, S., 2005. The economic implications of corporate financial reporting. Journal of Accounting and Economics 40 (1-3), 3-73.

Hanlon, M., 2005. The persistence and pricing of earnings, accruals, and cash flows when firms have large book-tax differences. The Accounting Review 80, 137-166.

Hanlon, M., Laplante, S., Shevlin, T., 2005. Evidence from the possible information loss of conforming book income and taxable income. The Journal of Law and Economics, 48, 407-442.

Hanlon, M., Maydew, E., 2006. Book-tax conformity: Implications for multinational firms, Working paper, University of Michigan, Ann Arbor, MI.

Hanlon, M., Maydew, E., Shevlin,T., 2006. Book-tax conformity and the information content of earnings, Working paper, University of Michigan. 
Hanlon, M., Shevlin, T., 2005. Book-tax conformity for corporate income: An introduction to the issues. In Poterba, J. (Ed.) Tax Policy and the Economy 19 National Bureau of Economic Research, MIT Press, Cambridge, MA, 101-134.

Hassett, K., Hubbard, R.G., 2002. Tax policy and business investment. In: Auerbach, A., Feldstein, M. (Eds.), Handbook of Public Economics Vol. 3, North-Holland, Amsterdam, 1293-1343.

Hassett, K., Newmark, K., 2006. Taxation and business behavior: A review of the recent literature, Working paper, American Enterprise Institute, Washington, D.C.

Healy, P., 1985. The effect of bonus schemes on accounting decisions. Journal of Accounting and Economics 7, 85-107.

Healy, P., Palepu, K., 2001. Information asymmetry, corporate disclosure, and the capital markets: A review of the empirical disclosure literature. Journal of Accounting and Economics 31, 405-440.

Joint Committee on Taxation, 2003. Report of Investigation of Enron Corporation and Related Entities Regarding Federal Tax and Compensation Issues, and Policy Recommendations, Volume I: Report. JCS-3-03.

Keating, S. Zimmerman, J., 2000. Asset lives for financial reporting purposes: Capital budgeting, tax and discretionary factors. Working paper. University of Rochester, Rochester, NY.

Kothari, S., 2001. Capital markets research in accounting. Journal of Accounting and Economics 31 (1-3), 105-231.

Krull, L., 2004. Permanently reinvested foreign earnings, taxes and earnings management. The Accounting Review 79 (3), 745-767.

Lev, B., Nissim, D., 2004. Taxable income, future earnings, and equity values. The Accounting Review, 1039-1074.

Lys, T., Vincent, L., 1995. An analysis of value destruction in AT\&T's acquisition of NCR. Journal of Financial Economics 39, 353-378.

Matsunaga, S., Shevlin, T., Shores, D., 1992. Disqualifying dispositions of incentive stock options: Tax benefits versus financial reporting costs. Journal of Accounting Research 30 (Supplement), 37-76.

Mills, L., 1998. Book-tax differences and Internal Revenue Service adjustments. Journal of Accounting Research 36 (2), 343-356. 
Mills, L., Newberry K., 2001. The influence of tax and non-tax costs on book-tax reporting differences: Public and private firms. The Journal of the American Taxation Association 23 (1), 1-19.

Neubig, T., 2006. Where's the applause? Why most corporations prefer a lower rate. Tax Notes (April 24), 483.

Phillips, J., Pincus, M., Rego, S. 2002. Earnings management: New evidence based on deferred tax expense. The Accounting Review 78 (2), 491-521.

Plesko, G., 1999. Book-tax differences and the measurement of corporate income. National Tax Association Proceedings, 171-176.

Robinson, L., 2006. Do firms pay for income statement classification? The effect of financial reporting on the market for housing tax credits. Working paper, Tuck School of Business at Dartmouth.

Sankar, M.R. Subramanyam, K.R. 2001. Reporting discretion and private information communication through earnings. Journal of Accounting Research 39 (2), 365386.

Schrand, C., Wong M., 2003. Earnings management using the valuation allowance for deferred tax assets under SFAS No. 109. Contemporary Accounting Research 20, 579-611.

Shackelford, D., Shevlin, T., 2001. Empirical research in accounting: A discussion. Journal of Accounting and Economics 31 (1-3), 321-387.

Schmidt, A., 2006. The persistence, forecasting, and valuation implications of the change component of earnings. The Accounting Review 81 (3), 589-616.

Scholes, M., Wolfson, M., 1992. Taxes and Business Strategy: A Planning Approach. Engelwood Cliffs, NJ: Prentice-Hall, Inc.

Stocken, P., Verrecchia, R., 2004. Financial reporting system choice and disclosure management. The Accounting Review 79 (4), 1181-1203.

Slemrod, J., 1992. Do taxes matter? Lessons from the 1980s. American Economic Review Papers and Proceedings, 82(2), 250-256.

Slemrod, J., 2001. A general model of the behavioral response to taxation. International Tax and Public Finance, 79(3), 119-128.

Weisbach, D., 2002. Ten truths about tax shelters, Tax Law Review, 55, 215-253. 